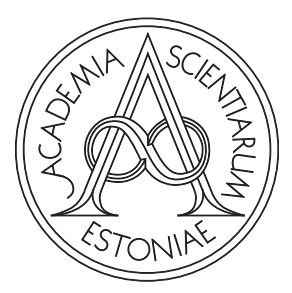

Proceedings of the Estonian Academy of Sciences, 2021, 70, 4S, 361-371

https://doi.org/10.3176/proc.2021.4S.08

Available online at www.eap.ee/proceedings

EYEWITNESS

MEMORY

\title{
Choosing lineup order vs knowing which lineup corresponds to which suspect: accuracy implications in multiple perpetrator identification
}

\begin{abstract}
Kristjan Kask
Centre of Excellence in Behavioural and Neural Sciences, School of Natural Sciences and Health, Tallinn University, Narva mnt 25, 10120 Tallinn, Estonia; kask@tlu.ee

Received 7 September 2020, accepted 26 July 2021, available online 4 October 2021

(C) 2021 Author. This is an Open Access article distributed under the terms and conditions of the Creative Commons AttributionNonCommercial 4.0 International License (http://creativecommons.org/licenses/by-nc/4.0/).

Abstract. Although many crimes involve multiple perpetrators, most eyewitness studies examine identification accuracy within the context of a single perpetrator. Prior research has indicated that stronger memory traces and lower cognitive load result in more accurate perpetrator identifications. In this study, 180 participants were shown a video of a simulated theft that involved two perpetrators. Afterwards, participants were randomly shown two lineups, each with a six-person simultaneous lineup. In one group $(n=60)$, the participant selected which lineup to view first; in the other groups, the administrator selected which lineup to view first. When the administrator chose the viewing order, half of the participants $(n=60)$ were aware of which lineup corresponded to which perpetrator and half $(n=60)$ were not. The participants who selected which lineup to view first correctly rejected target-absent lineups more often $(65 \%)$ than those who did not know which lineup corresponded to which perpetrator (45\%). There were no differences between the participants who selected which lineup to view first and those who could not choose the order but were aware which lineup corresponded to which perpetrator. In conclusion, being aware of which lineup corresponds to which perpetrator seems to be an important factor associated with eyewitnesses' cognitive load.
\end{abstract}

Key words: eyewitness identification, multiple perpetrators, simultaneous lineups, memory trace strength, cognitive load.

\section{INTRODUCTION}

The Innocence Project (2020) reports that $70 \%$ of DNA exonerations have involved one or more mistaken eyewitnesses. Similarly, nearly $30 \%$ of the 2228 exoneration cases in the U.S. since 1989 have involved one or more mistaken identifications (National Registry of Exonerations 2017). However, up to $70 \%$ of crimes against minorities are committed by two or more perpetrators (European Union Agency for Fundamental Rights 2012). In the UK, the percentage of crimes involving four or more perpetrators increased from $19 \%$ to $25 \%$ between 2003 and 2008 (Home Office Research Development Statistics 2009, as cited in Hobson and Wilcock 2011), and nearly $15 \%$ of eyewitnesses viewed two or more lineups during the course of the police investigations (Halford 2009). As most research in the area of eyewitness identification has examined single-perpetrator identification accuracy, it is important to also examine the factors influencing multipleperpetrator identification accuracy (Horry et al. 2014; see also Kask and Bull 2009).

Identification accuracy decreases when there is more than one perpetrator (see Clifford and Hollin 1981; Shepherd 1983; Sauerland et al. 2013). For example, Clifford and Hollin (1981) detected that, compared to single perpetrator lineups, identification accuracy decreased when eyewitnesses were asked to identify either three or five culprits. Similar results have been reported in facial recognition (see Megreya and Burton 2006; Megreya and Bindemann 2012). Nortje et al. (2015) examined the effects of set size (i.e., number of faces) on facial recognition and established that larger set sizes 
impaired memory for faces and actions. This suggests that eyewitness accuracy is inversely related to the number of perpetrators.

When witnesses see more than one person at a time, their attention is divided, resulting in poorer recognition later (Megreya and Bindemann 2012). Poor recognition is also related to perceptual interference (Bindemann et al. 2012). Johnson et al. (1993) explained this using the theory of source memory. Specifically, when witnessing an event, witnesses generally remember the source of the encoded information; however, when a witness' attention is divided, there could be less accurate information to be encoded resulting in difficulty in retrieving accurate information. Thus, it may be difficult for an eyewitness to differentiate between memories, resulting in inaccurate identification (see also Hobson and Wilcock 2011).

A strong memory is generally assumed when a stimulus can be retrieved from memory quickly, accurately, and confidently; weak memory is characterized by less efficient, less accurate, and less confident retrieval (Kafkas and Montaldi 2011). When a crime has more than one perpetrator, identification accuracy decreases. Difficulty in correctly identifying perpetrators from a lineup may be related to memory trace strength. Leippe and Eisenstadt (2007) noted that stronger witness memory traces correlated with more accurate suspect identification. For example, individuals with weak memory traces tend to perform worse when viewing multiple lineups for the same suspect (Godfrey and Clark 2010). Thus, individuals' perceived memory strength may have an effect on subsequent lineup decisions. On the other hand, Mansour et al. (2017) examined multiple-trial experiments in eyewitness identification studies and detected that the rates of correct identification did not vary significantly across the trials. It could be suggested that eyewitnesses put stronger memory traces first: when eyewitnesses are able to choose which lineup to view first, they may initially leverage stronger memory traces to increase the proportion of accurate identifications in multiple perpetrator crimes.

Perpetrators can take different roles in a crime. For example, a robbery may include a thief, an accomplice, and/or a driver (see Clifford and Hollin 1981; Sauerland and Sporer 2008; Sauerland et al. 2013; Nortje et al. 2016; Nortje 2018). Nortje et al. (2016) conducted a study where participants viewed a staged theft by one, two, three, five, or ten perpetrators. Following a 30-minute delay, participants viewed as many lineups as there were perpetrators. Some lineups were target-present (TP), while others were target-absent (TA). Identification performance decreased as the number of perpetrators increased, and accurate identification was worst when participants were asked to link perpetrators to roles. It could be that the suspect in all these roles can be involved differently in committing the crime, and that the role of the perceiver has mainly been an eyewitness in studies using this design but not a victim (where the perception and thus emotional meaning of the situation would be completely different).

Moreover, it has been established that eyewitnesses may sometimes misremember the roles played by different actors within an event (Kersten et al. 2013). Previous studies examining eyewitness memory for roles within an event (e.g., Geiselman et al. 1996; Wells and Pozzulo 2006) have found little evidence for such role transference. However, Kersten et al. (2013) demonstrated that eyewitnesses more frequently associate an actor with the actions of another person when those two people appear together in the same event, rather than in different events. They proposed that the studies cited above involved actions that were clearly criminal (e.g., purse snatching), whereas in their research, the actions were ordinary (e.g., everyday activities).

If perpetrators look very different and witness descriptions are very good (for review, see Meissner et al. 2007), then police officer(s) may be able to easily indicate which lineup corresponds to which perpetrator. However, when perpetrators are visually similar or act in a similar manner, this can increase cognitive load in eyewitnesses. According to the cognitive load hypothesis, individuals have a limited pool of cognitive resources (Glenberg 1997; see also Sweller 1988; Sweller et al. 2011). Glenberg (1997) proposed that the primary purpose of memory is to serve action, and when recollection is difficult, environmental monitoring must be suppressed to allow internal control over this complex cognitive process (see also Vredeveldt et al. 2011). Therefore, to test the memory trace strength hypothesis, it is important to examine identification accuracy in cases where the eyewitness is either aware or not aware of which lineup corresponds to which perpetrator. Being aware of which lineup corresponds to which perpetrator decreases cognitive load, allowing the eyewitness to focus more on activating the specific memory traces necessary to identify the person in question. Conversely, being unaware increases cognitive load and may negatively affect identification accuracy.

\section{THE PRESENT STUDY}

In eyewitness identification research, it is important to assess whether system variables affect eyewitness accuracy. For example, the way in which lineups are presented is under the control of the justice system (see Wells 1978).

Equally important is the witness' ability to distinguish the guilty suspect (the individual who committed the crime) from the innocent suspect (an individual whom the police incorrectly suspect of committing the crime). This 
is called discriminability (Mickes and Gronlund 2017). There are different statistics to assess discriminability, such as $d$ ' (Mickes and Gronlund 2017). Higher $d$ ' values refer to better discriminability. In recent research, Nortje (2018) reported that in a study about single perpetrators a guilty suspect was discriminated better than an innocent suspect, $d^{\prime}=1.53$. For two perpetrators, the $d^{\prime}$ 'value was .79 , and for multiple perpetrators (two, three, five, and ten), the combined $d$ ' value was .87 .

In addition to discriminability, it is also important to examine the impact of eyewitness confidence on accurate suspect identification. Eyewitness reliability is defined as the likelihood that the identified suspect is guilty (Mickes and Gronlund 2017). Studies indicate that eyewitness confidence and accuracy of suspect identification have a strong positive relationship under certain conditions (e.g., fair lineups with no lineup administrator influence, and with an immediate confidence statement, see Wixted and Wells 2017). Wixted et al. (2016) add that eyewitness confidence is a highly reliable indicator of accuracy. Eyewitness identification reliability is assessed via positive predictive value (PPV), or the probability that an identified individual is actually the perpetrator. The relationship between the subjective probability that an identification is accurate and the objective probability that it is accurate is measured by calibration analysis (Mickes 2015). Confidence-accuracy calibration (CAC) analysis is a close relative of calibration analysis that only considers suspect identifications (Mickes 2015). To compute the CAC-dependent variable, correct suspect identifications (IDs) are divided by the sum of the correct and incorrect suspect IDs - the higher the PPV, the stronger the association between accurate identification and confidence. It is important to note that both $d^{\prime}$ and CAC characteristics are not statistical analyses per se, but rather methods to help describe performance in memory tasks.

The present study investigated the relationship between identification accuracy, lineup viewing order, and awareness of which simultaneous lineups correspond to which perpetrator. Our hypotheses were as follows.

First, we hypothesized that witnesses would be more likely to make accurate identifications (i.e., correct identifications from TP lineups and correct rejections from TA lineups) when witnesses could choose the lineup order themselves, rather than the administrator choosing the order. This hypothesis is based on the memory trace strength approach, which predicts that stronger witness memory about a specific perpetrator will result in faster and more accurate information retrieval (Kafkas and Montaldi 2011). To test memory trace strength, some witnesses would be allowed to choose which lineup they saw first.

Second, we expected that when the administrator chooses the order of the lineups but witnesses are aware of which lineup corresponds to which perpetrator, witnesses are more accurate compared to when they are not aware of which lineup corresponds to which perpetrator. This hypothesis is based on the cognitive load approach, which states that individuals have limited cognitive resources (Glenberg 1997). Being aware of which lineup corresponds to which perpetrator would decrease cognitive load as witnesses could focus more on activating those memory traces necessary to identify the person in question.

Third, we expected that witnesses' ability to distinguish guilty suspects from innocent suspects would be higher if the witnesses were told which lineup corresponds to which perpetrator. In addition, we expected that greater witness confidence would correlate with higher identification accuracy.

\section{METHODS}

\section{Sample}

The sample consisted of 180 students (69 males, 111 females) with a mean age of 23.5 years $(S D=3.34$; range $=17-34$ ). Tallinn Ethics Committee of Medical Research granted approval for conducting all research.

\section{Design}

This study used a 3 (condition: No Choice Not Blind [NCNB] vs No Choice Blind [NC-B] vs Choice, [C]) $\times 2$ (target presence: TP vs TA simultaneous lineups) betweensubjects factorial design. In the NC-NB condition, the experimenter chose the order of viewing the lineups but told the eyewitnesses which perpetrator the lineup was going to include. In the NC-B condition, the experimenter chose the order of viewing the lineups but did not tell the participant which perpetrator the lineup was going to include. In the $\mathrm{C}$ condition, the participant chose the order of viewing the lineups.

\section{Materials}

Stimulus video. A stimulus video of a simulated robbery was filmed using a Canon XA20 video camera. The video featured two young men in their 20s (the perpetrators) who were both equally engaged in stealing a wallet and a mobile phone from a similar-aged young woman (the victim). The event was staged indoors with good lighting conditions. The video was filmed from an eyewitness' perspective and lasted 59 seconds. The perpetrators and their faces were visible for a comparable amount of time. The victim's face was also visible to the eyewitness. Perpetrator 1 (positioned to the left of the victim) stole the 
victim's mobile phone, while Perpetrator 2 (positioned to the right of the victim) stole the victim's wallet.

Construction of lineups. Two six-person either TP and TA simultaneous lineups were constructed. All foils (persons similar to the suspect) and the replacement (i.e., the innocent suspect in a TA lineup) fit the general description of a reference target according to Doob and Kirshenbaum (1973). Effective sizes for the lineups, determined as Tredoux's E values (estimates the number of persons in the lineup who are realistic choices given the verbal description of the perpetrator), were 3.1 for Perpetrator 1 and 5.6 for Perpetrator 2 (Tredoux 1998). Thus, six-person lineups could be created.

Head-and-shoulder colour photos of the male perpetrators were taken with a Nikon d5100 camera. We created twenty-four different versions of lineups to randomize the order of the targets, target replacements, foils, perpetrators, and perpetrator replacements. For each perpetrator, six TP and six TA simultaneous lineups were constructed for randomization purposes.

\section{Procedure}

The participants were tested individually in the experimental psychology laboratory of Tallinn University, Estonia. First, they signed a consent form to participate in the experiment. Next, the participants watched the robbery video on a 23 -inch monitor. The participants were only instructed, "Please watch a videoclip." After that, they completed a distractor task: the Stroop Colour and Word Test (Stroop 1935) using the computer program PsychoPy (Peirce 2007). This distractor task took about five minutes. Subsequently the participants provided free-recall descriptions of the perpetrators who were seen in the video. Then, the participants completed a second distractor task: a dichotic listening test based on the Bergen Dichotic Listening paradigm (Hughdahl 2003). This second distractor task took about 10-12 minutes to complete. The participants completed this task using either the iDichotic iOS application (iDichotic App 2015) on an iPad 2 (Apple Inc., Cupertino, CA) or E-Prime 2.0 software (Psychology Software Tools 2017). Auditory stimuli were presented through Sennheiser HD202 headphones. The two distractor tasks were conducted to create temporal distance between seeing the stimulus video and presenting the lineup. These specific tasks were chosen as they required participants to focus attention on various different stimuli - namely, visually and aurally presented words. Finally, the participants viewed two lineups that were presented as a Microsoft PowerPoint 2013 slideshow on a 23-inch monitor. The time delay between seeing the video clip and viewing the lineups was approximately 20-25 minutes.
The participants in the NC-B group $(n=60)$ were told that the perpetrator may or may not be in the lineup (see Technical Working Group for Eyewitness Evidence 1999). For each lineup, the six photos were presented in two rows, with three photos in each row. After a decision had been made, the participants rated their confidence on a 10 -point Likert scale ( $1=$ not sure at all; $10=$ sure $)$. The presence or absence of targets was randomized and used to balance the data collection: one target was always present and the other target always absent in the lineups. The participants were not told that a lineup corresponded to a particular perpetrator; they were simply told, "I will now show you the first lineup," and, "I will now show you the second lineup."

For the participants in the NC-NB group $(n=60)$, the experimenter chose the order of viewing the lineups but told the eyewitnesses which perpetrator the lineup was going to include (i.e., "I will now show you a lineup for the perpetrator who was on the left [or right] in the video").

The participants in the C group $(n=60)$ also viewed two lineups, but they were allowed to choose the order in which they viewed the lineups. That is, the participants could first view the lineup for the perpetrator who appeared on the left, then view the second lineup for the perpetrator who appeared on the right, or vice versa.

A yoked control procedure (Salkind 2010) was applied to determine the lineup order in the NC groups. Based on how often the participants chose the viewing order of lineups in the $\mathrm{C}$ group, a similar proportion of lineups in the same order was shown to the participants in the NC groups.

\section{Power analysis}

In each group, there were 30 participants per group, which is consistent with the norm of including approximately 20 participants per cell (Wilcock et al. 2018). A post hoc power analysis on the entire sample $(n=180)$ was conducted by means of the software package GPower (Faul et al. 2009). The recommended effect sizes used for this assessment were small $(w=.10)$, medium $(w=.30)$, and large $(w=.50$; see Cohen 1988). The alpha level used for this analysis was $p<.05$. The post hoc analyses indicated that statistical power was .21 for detecting a small effect, .96 for detecting a medium effect, and .99 for detecting a large effect. In sum, there was adequate power at the medium and large effect sizes, but less than adequate statistical power to detect a small effect size.

\section{Statistical analyses}

First, data regarding identification accuracy were dichotomized, i.e., correct identifications in TP lineups and 
correct rejections in TA lineups were considered accurate decisions, while foil identifications or incorrect lineup rejections in TP lineups and foil or target replacement identifications in TA lineups were considered inaccurate decisions. To examine whether accurate decisions in a lineup presented first could predict accurate decisions in a lineup presented second, Generalized Estimating Equations (GEE) was used as the measures were repeated. The proportion of accurate and inaccurate decisions was analysed with the help of logistic regression analysis with Bonferroni correction $(p<.017)$. Chi-square tests and ANOVAs were used to compare gender, age, and education differences between the three groups. For all tests, $p$-values $<.05$ (one-tailed) were considered statistically significant. All analyses were performed using IBM SPSS software version 27.

\section{RESULTS}

The overall identification accuracy characteristics are reported in Table 1. The three groups of participants did not differ significantly in terms of participant gender, $\chi^{2}(2)=2.96, p=.23$, education, $\chi^{2}(6)=8.47, p=.21$, or age, $F(2,179)=.07, p=.93$. GEE was used to test whether accurate decisions in a lineup presented first could predict accurate decisions in a lineup presented second. The predictor was accuracy in identifying the perpetrator presented in the first lineup, while the dependent variable was accuracy in identifying the perpetrator presented in the second lineup. The model did not predict the effect, $\chi^{2}(1)=.43, p=.511$, thus perpetrator position (i.e., whether appearing in the first or second lineup) did not have an effect on identification accuracy.

\section{Identification accuracy}

To examine the effect of condition on lineup accuracy, a series of logistic regression analyses was conducted

Table 1. The number and proportion of accurate and inaccurate identifications as a function of who chooses the lineup order

\begin{tabular}{l|l|l|l}
\hline Accuracy & NC-B & NC-NB & C \\
\hline None & $26(43 \%)$ & $16(27 \%)$ & $13(22 \%)$ \\
One & $21(35 \%)$ & $28(46 \%)$ & $36(60 \%)$ \\
Both & $13(22 \%)$ & $16(27 \%)$ & $11(18 \%)$ \\
Total & $60(100 \%)$ & $60(100 \%)$ & $60(100 \%)$
\end{tabular}

Note. Accurate $=$ correct identification in a TP lineup, or correct rejection of a TA lineup; Inaccurate $=$ identification of a foil from a TP or TA lineup, or incorrect rejection of a TP lineup; NC-B = No Choice Blind; NC-NB = No Choice Not Blind; $\mathrm{C}=$ Choice. separately for TP and TA lineups using Bonferroni correction $(p<.017)$. Decision accuracy (accurate or inaccurate) was the dependent variable and condition types (C and NC-B, C and NC-NB, or NC-B and NC-NB) were the predictor variables. One model for TA lineups $\left(\mathrm{C}\right.$ and NC-B) was significant, $\chi^{2}(1)=8.08, p=.004$ $\left(R=.066, R^{2}=0.089\right)$ indicating that the participants in the $\mathrm{C}$ group rejected the lineup correctly to a larger extent than the participants in the NC-B group $(B=-1.081$, $S E B=.388$, Wald $=7.76, p=.005, \beta=.339$ [.159-.726]).

\section{Discriminability and reliability measures}

To measure discriminability (see Table 2), $d$ ' values were calculated according to Mickes et al. (2014) using the formula $d^{\prime}=z$ (correct suspect identification rate in TP lineups) $-z$ (false suspect replacement identification rate in TA lineups) (see also Macmillan and Creelman 2005). As this study did not include a designated suspect replacement, the number of false identifications was divided by the number of individuals in the lineup. The NC-B group showed the lowest discriminability $\left(d^{\prime}=.86\right)$. $D^{\prime}$ values were higher for the NC-NB group $\left(d^{\prime}=1.31\right)$ and for the $\mathrm{C}$ group $\left(d^{\prime}=1.10\right)$. This indicates that in the NC-NB and C groups the guilty suspects were better discriminated from the innocent suspects than in the NC-B group. However, when the lineups for both perpetrators were observed separately, $d$ ' values for Perpetrator 1 were higher $\left(d^{\prime}=1.25-1.46\right)$ than for Perpetrator $2\left(d^{\prime}=0.49-1.13\right)$.

We examined further the relationship between confidence and accuracy by means of CACs (Mickes 2015) and summed confidence values into three levels according to Mickes (2015): 1-6 for low, 7-8 for medium, and 9-10 for high (see Table 3). Then we calculated conditional probability or positive predictive values (PPVs) (e.g., given a suspect ID, what is the likelihood that the suspect was guilty?). PPVs were represented as guilty suspect IDs (guilty suspect IDs + innocent suspect IDs). As this study did not include a designated suspect replacement, the number of false identifications was divided by the number of individuals in the lineup. For the NC-B group, PPVs were .63, .88, and .92; for the NC-NB group, PPVs were $.82, .88$, and .94; and for the C group, PPVs were .71, .93, and 1.00 .

These results indicate that higher identification accuracy correlates with higher confidence. When confidence was lowest, PPVs of the NC-B group were lower than for other groups; however, when confidence levels were higher, PPVs of the C group were higher (.93 and 1.00 , respectively) than in other groups (range $=.88-.94$ ). When the lineups for both perpetrators were observed separately, PPV variance between Perpetrators 1 and 2 differed for the NC-NB group, indicating a stronger 
Table 2. Identification accuracy and discriminability scores of Perpetrators 1 and 2 in TP and TA lineups

\begin{tabular}{|c|c|c|c|c|c|}
\hline & $\begin{array}{c}\text { Lineup } \\
\text { type }\end{array}$ & Accuracy & NC-B & NC-NB & $\mathrm{C}$ \\
\hline \multirow[t]{6}{*}{ Perpetrator 1} & TP & Correct identification & $14(48 \%)$ & $14(48 \%)$ & $11(38 \%)$ \\
\hline & & Foil identification & $8(28 \%)$ & $7(24 \%)$ & $10(34 \%)$ \\
\hline & & Incorrect rejection & $7(24 \%)$ & $8(28 \%)$ & $8(28 \%)$ \\
\hline & TA & Correct rejection & $13(42 \%)$ & $19(61 \%)$ & $23(74 \%)$ \\
\hline & & Foil identification & $18(58 \%)$ & $12(39 \%)$ & $8(26 \%)$ \\
\hline & $d$ & & 1.25 & 1.46 & 1.41 \\
\hline \multirow[t]{6}{*}{ Perpetrator 2} & $\mathrm{TP}$ & Correct identification & $5(16 \%)$ & $12(39 \%)$ & $8(26 \%)$ \\
\hline & & Foil identification & $10(32 \%)$ & $10(32 \%)$ & $7(23 \%)$ \\
\hline & & Incorrect rejection & $16(51 \%)$ & $9(29 \%)$ & $16(51 \%)$ \\
\hline & TA & Correct rejection & $14(48 \%)$ & $15(52 \%)$ & $16(55 \%)$ \\
\hline & & Foil identification & $15(52 \%)$ & $14(48 \%)$ & $13(45 \%)$ \\
\hline & $d$ & & .49 & 1.13 & .80 \\
\hline \multirow[t]{6}{*}{ Combined } & TP & Correct identification & $19(32 \%)$ & $26(44 \%)$ & $19(32 \%)$ \\
\hline & & Foil identification & $18(30 \%)$ & $17(28 \%)$ & $17(28 \%)$ \\
\hline & & Incorrect rejection & $23(38 \%)$ & $17(28 \%)$ & $24(40 \%)$ \\
\hline & TA & Correct rejection & $27(45 \%)$ & $34(57 \%)$ & $39(65 \%)$ \\
\hline & & Foil identification & $33(55 \%)$ & $26(43 \%)$ & $21(35 \%)$ \\
\hline & $d^{\prime}$ & & .86 & 1.31 & 1.10 \\
\hline
\end{tabular}

Note. $\mathrm{TP}=$ Target-Present lineup; $\mathrm{TA}=$ Target-Absent lineup; $\mathrm{NC}-\mathrm{B}=$ No Choice Blind , NC-NB = No Choice Not Blind; $\mathrm{C}=$ Choice.

association between accurate identification and confidence for Perpetrator 1 than for Perpetrator 2. However, it should be considered that the number of responses in each cell was low.

\section{DISCUSSION}

The present study examined the relationship between eyewitness identification accuracy, the order of viewing lineups, and whether eyewitnesses can ascertain which lineup corresponds to which perpetrator.

According to the first hypothesis, we expected that eyewitnesses would be more likely to correctly identify suspects from TP lineups and correctly reject suspects from TA lineups when the eyewitnesses could choose the lineup order themselves (as compared to when a lineup administrator chose the order). This hypothesis was based on the memory trace strength theory, which suggests that when a witness' memory about one perpetrator is stronger, the witness can retrieve information from memory more quickly and with higher accuracy (Leippe and Eisenstadt 2007; Kafkas and Montaldi 2011).

Second, we hypothesized that witnesses would make more accurate decisions when aware of which lineup corresponds to which perpetrator - even when a lineup administrator chooses the viewing order of the lineups. This hypothesis was based on the cognitive load theory 


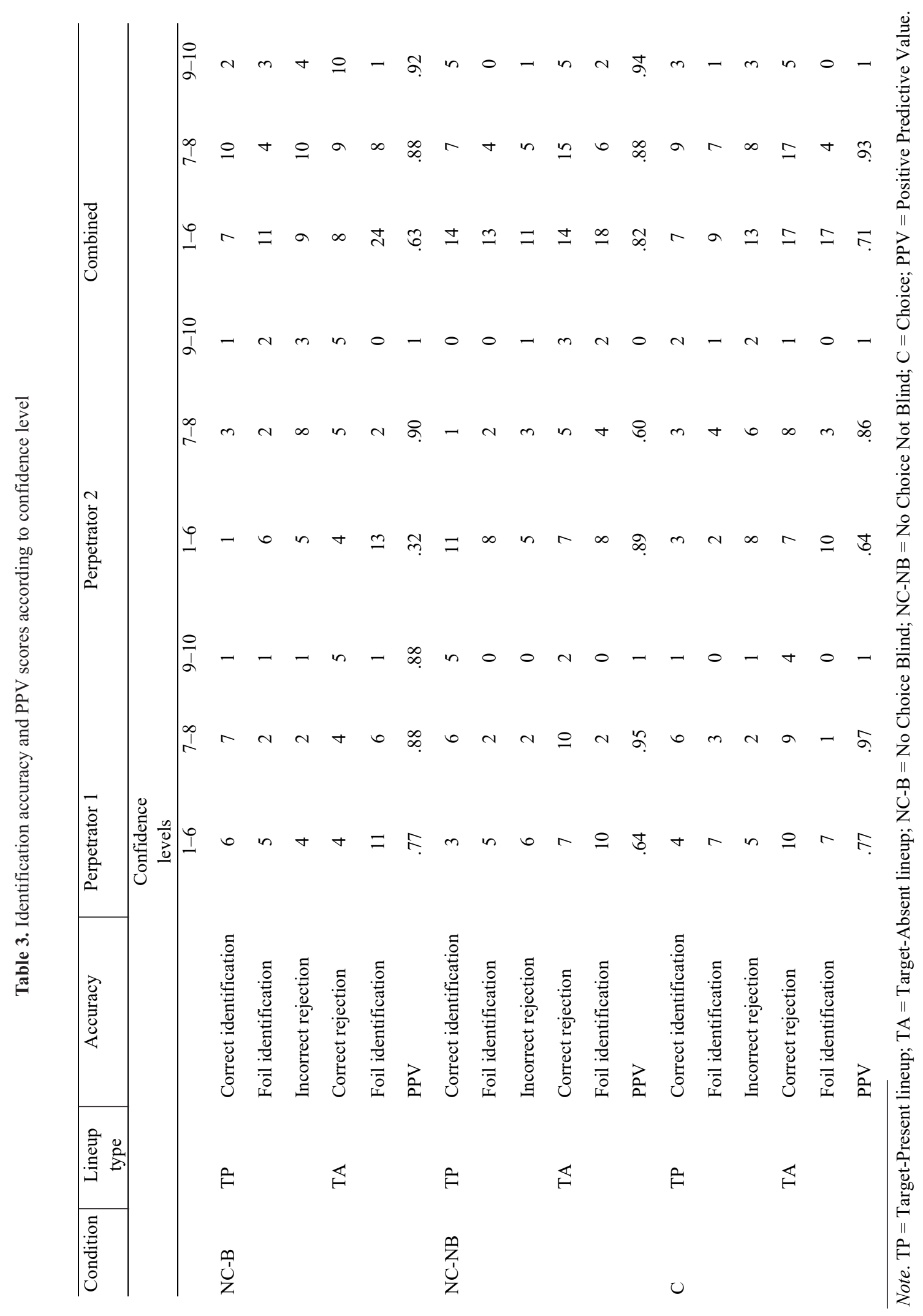


(Glenberg 1997), which indicates that if witnesses know which lineup corresponds to which perpetrator, then decision accuracy is higher.

There were no significant differences between the groups regarding identification accuracy from TP lineups. However, when the rate of rejection accuracy from TA lineups was examined, the $\mathrm{C}$ group had a significantly higher $(65 \%)$ correct rejection rate as compared to the NC-B group (45\%) (comparisons between other groups showed no significant results). Based on these results, partial support for the hypothesis was confirmed. The correct rejection rate was higher in the $\mathrm{C}$ group than in the NC-B group, which indicates that the ability to choose the lineup viewing order is, in some circumstances, beneficial.

However, as there were no significant differences between the $\mathrm{C}$ and $\mathrm{NC}-\mathrm{NB}$ groups, the more crucial factor is the issue of decreasing cognitive load-i.e., whether the witness knows which lineup corresponds to which perpetrator. To better interpret the results, we also analysed discriminability and reliability measures. For the NC-B group, discriminability was lower compared to the other two conditions. Regarding reliability measures, as compared to the PPVs of the C and NB-NC groups, the PPVs of the NC-B group were especially low for the low (1-6) and high (9-10) confidence estimations. Thus, an eyewitness' awareness of which lineup corresponds to which perpetrator has a larger effect on identification decisions than a witness' ability to decide which lineup to see first (see Sweller 1988; Glenberg 1997; Sweller et al. 2011). On the other hand, when the suspect(s) were present in the lineup(s), there were no differences in decision accuracy between the groups. Therefore, knowing which lineup corresponds to which perpetrator is especially important when the suspect may be absent from the lineup. Indeed, prior research has shown that it can be more difficult for witnesses, such as children or older adults, to make correct rejections from TA lineups than to make correct identifications from TP lineups (Pica and Pozzulo 2018).

\section{Limitations and future directions}

In previous studies, multiple perpetrators played different roles in the mock crime scenario (Clifford and Hollin 1981; Sauerland et al. 2013; Nortje et al. 2016). In the present study, however, both perpetrators were equally engaged in the crime; that is, they both tried to get the victim's attention and they both tried to steal the victim's belongings. This may explain why relatively few participants were able to correctly identify both perpetrators. In addition, we must consider that the victim's face was also visible to the eyewitnesses in our study, which may have attracted the eyewitnesses' attention.
In addition, according to discriminability and reliability measures, identification accuracy varied strongly in relation to confidence measures between Perpetrators 1 and 2. Namely, $d$ ' values for Perpetrator 1 were higher than for Perpetrator 2, which may indicate that the lineups for Perpetrator 1 discriminated the guilty suspect from innocent suspects better than the lineups for Perpetrator 2. As Tredoux E values for Perpetrators 1 and 2 also differed, then this difference could explain the difference in discriminability measures as well. When PPVs were examined, Perpetrators 1 and 2 differed to a large extent. This suggests a stronger association between accurate identification and confidence in Perpetrator 1. Thus, future researchers should replicate this study applying several scenarios and stimuli, while counterbalancing the position of the stimuli between participants.

Another limitation to this study is how eyewitnesses described perpetrators and, based on their descriptions, how lineups were constructed and presented (see Nortje et al. 2016). In the future, it would be worthwhile to simulate a misinterpretation between the eyewitness and administrator, such that the eyewitness views a lineup containing a different perpetrator than what the eyewitness had in mind. This situation could happen in practice when perpetrators look visually similar, when perpetrators have similar behaviours, or when investigators collect descriptions from eyewitnesses in a poor manner.

Finally, the present results may have been affected by time delay. In the current study, the participants were shown lineups within 20-25 minutes of observing the stimulus event. In actual crimes, however, witnesses may wait weeks or even months before they are asked to view a lineup (see Kask and Lebedeva 2015).

In future research, the position of perpetrators in the visual field (i.e., left or right) should be randomized. In studies of divided visual fields, the left visual field is reported to be dominant (see Hole and Bourne 2010). However, this effect may be outweighed by the memorability of certain physical characteristics of the perpetrators, especially if those characteristics are distinctive. By randomizing the perpetrator's position in the visual field, future investigators could more easily understand if the position of the perpetrator is related to identification accuracy. Future studies may also use eye tracking to examine eyewitness decision accuracy in relation to attention, both when observing stimuli and later in the identification phase.

\section{CONCLUSIONS}

The majority of the existing research in the area of eyewitness identification has been conducted with single perpetrators, thus we know little about the identification of multiple perpetrators. The results of this study indicate 
that in terms of correct rejections from TA lineups, an eyewitness' knowledge of which lineup corresponds to which perpetrator more strongly influences eyewitness decisions compared to a witnesses' ability to decide lineup viewing order. Therefore, when conducting lineups for multiple perpetrators, it is important to indicate to the witness, when possible, which lineups corresponds to which perpetrator, as this could lower incorrect identification of innocent suspects from TA lineups.

\section{ACKNOWLEDGEMENTS}

This research was supported by Tallinn University Research Fund Project TF1515 "The Centre of Excellence in Behavioural and Neural Science" and Tallinn University ASTRA Project "TU TEE - Tallinn University as a promoter of intelligent lifestyle". This research was financed by the European Union European Regional Development Fund 2014-2020.4.01.16-0033 and the Baltic-American Freedom Foundation. The author wishes to thank Tairi Lääts, Mariliis Martin, and Ave Alviste for selecting and taking photos of the perpetrators and foils; Amaranta Heredia for filming the stimulus video clip; Tairi Lääts, Mariliis Martin, Ave Alviste, Helena Eidast, Liis Jürioja, Heelika Aus, Karolyn Schiff, Kristina Oras, Sander Murumaa, Moonika Tamm, Hendrik Martin Hendrikson, Janne Kalda, and Gea Rumjantseva for collecting the data; Lawrence T. White, Josephine Hirsch, and Dashiell Stanford for their valuable comments regarding the written paper. The publication costs of this article were covered by the Estonian Academy of Sciences.

\section{REFERENCES}

Bindemann, M., Sandford, A., Gillatt, K., Avetisyan, M. and Megreya, A. M. 2012. Recognising faces seen alone or with others: Why are two heads worse than one? Perception, 41(4), 415-435. https://doi.org/10.1068/p6922

Clifford, B. R. and Hollin, C. R. 1981. Effects of the type of incident and the number of perpetrators on eye-witness memory. J. Appl. Psychol., 66(3), 364-370.

Cohen, J. 1988. Statistical Power Analysis for the Behavioural Sciences. 2nd ed. Academic Press, New York, NY.

Doob, A. N. and Kirshenbaum, H. M. 1973. The effects on arousal of frustration and aggressive films. J. Exp. Soc. Psychol., 9(1), 57-64.

European Union Agency for Fundamental Rights (FRA). 2012. EUMIDIS Data in Focus Report 6: Minorities as Victims in Crime. http://fra.europa.eu/en/publication/2012/ eu-midis-data-focusreport-6-minorities-victims-crime

Faul, F., Erdfelder, E., Buchner, A. and Lang, A.-G. 2009. Statistical power analyses using G*Power 3.1: Tests for correlation and regression analyses. Behav. Res. Methods, 41, 1149-1160. https://doi.org/10.3758/BRM. 41.4.1149
Geiselman, R. E., Haghighi, D. and Stown, R. 1996. Unconscious transference and characteristics of accurate and inaccurate eyewitnesses. Psychol. Crime Law, 2(3), 197209. https://doi.org/10.1080/10683169608409778

Glenberg, A. M. 1997. What memory is for: Creating meaning in the service of action. Behav. Brain Sci., 20(1), 41-50. https://doi.org/10.1017/S0140525X974 70012

Godfrey, R. D. and Clark, S. E. 2010. Repeated eyewitness identification procedures: Memory, decision making, and probative value. Law and Human Behavior, 34(3), 241-258. https://doi.org/10.1007/s10 979-009-9187-7

Halford, P. 2009. Eyewitness identification in real world conditions. Unpublished doctoral dissertation. Flinders University, Adelaide, SA, Australia.

Hobson, Z. J. and Wilcock, R. 2011. Eyewitness identification of multiple perpetrators. I. J. Police Sci. Manag., 13(4), 286296. https://doi.org/10.1350/ ijps.2011.13.4.253

Hole, G. and Bourne, V. 2010. Face Processing: Psychological, Neuropsychological, and Applied Perspec- tives. Oxford University Press.

Home Office Research Development Statistics. 2009. http://rds. homeoffice.gov.uk/rds/bcs1.html (accessed 2010-05-24).

Horry, R., Halford, P., Brewer, N., Milne, R. and Bull, R. 2014. Archival analyses of eyewitness identification test outcomes: What can they tell us about eyewitness memory? Law Hum. Behav., 38(1), 94-108. https://doi.org/10.1037/lhb0000060

Hugdahl, K. 2003. Dichotic listening in the study of auditory laterality. In The Asymmetrical Brain (Hughdahl, K. and Davidson, J., eds), pp. 441-476, MIT Press, Cambridge, MA.

Innocence Project. 2020. http://www.innocenceproject.org (accessed 2020-08-10).

Johnson, M. K., Hashtroudi, S. and Lindsay, D. S. 1993. Source monitoring. Psychol. Bull., 114(1), 3-28. https://doi.org/ 10.1037/0033-2909.114.1.3

Kafkas, A. and Montaldi, D. 2011. Recognition memory strength is predicted by pupillary responses at encoding while fixation patterns distinguish recollection from familiarity. The Q. J. Exp. Psychol., 64(10), 1971-1989. https://doi.org/ 10.1080/17470218.2011.588335

Kask, K. and Bull, R. 2009. The effects of different presentation methods on multi-ethnicity face recognition. Psychol. Crime Law, 15(1), 73-89. https://doi.org/10.1080/ 10683160802131131

Kask, K. and Lebedeva, R. 2015. Identification parades in Estonia: The state of the art. Proceedings: Estonian Academy of Security Sciences, 14, 25-48.

Kersten, A. W., Earles, J. L. and Upshaw, C. 2013. False recollection of the role played by an actor in an event. Mem. Cogn., 41, 1144-1158. https://doi.org/10.3758/s 13421-0130334-5

Leippe, M. R. and Eisenstadt, D. 2007. Eyewitness confidence and the confidence-accuracy relationship in memory for people. In Handbook of Eyewitness Psychology: Memory for People, vol II (Lindsay, R. C. L., Ross, D. F., Read, J. D. and Toglia, M. P., eds), pp. 377-425, Lawrence Erlbaum Associates, Mahwah, NJ.

Mansour, J. K., Beaudry, J. L. and Lindsay, R. C. L. 2017. Are multiple-trial experiments appropriate for eyewitness identification studies? Accuracy, choosing, and confidence 
across trials. Behav. Res., 49, 2235-2254. https://doi.org/ 10.3758/s13428-017-0855-0

Macmillan, N. A. and Creelman, C. D. 2005. Detection Theory: A User's Guide. Lawrence Erlbaum Associates, Mahwah, NJ.

Megreya, A. M. and Bindemann, M. 2012. Identification accuracy for single- and double-perpetrator crimes: Does accomplice gender matter? Br. J. Psychol., 103(4), 439-453. https://doi.org/10.1111/j.2044-8295. 2011.02084.x

Megreya, A. M. and Burton, A. M. 2006. Recognising faces seen alone or with others: When two heads are worse than one. Appl. Cogn. Psychol., 20(7), 957-972. https://doi.org/10.1002/ acp. 1234

Meissner, C. A., Sporer, S. L. and Schooler, J. W. 2007. Person descriptions as eyewitness evidence. In Handbook of Eyewitness Psychology: Memory for People, vol. II (Lindsay, R. C. L., Ross, D. F. and Toglia, M. P., eds), pp. 3-34, Lawrence Erlbaum Associates, Mahwah, NJ.

Mickes, L. 2015. Receiver operating characteristic analysis and confidence-accuracy characteristic analysis in investigations of system variables and estimator variables that affect eyewitness memory. J. Appl. Res. Mem. Cogn., 4(2), 93102. https://doi.org/ 10.1016/j.jarmac.2015.01.003

Mickes, L. and Gronlund, S. D. 2017. Eyewitness identification. In Learning and Memory: A Compre- hensive Reference. 2nd ed. (Byrne, J. H., ed.), pp. 529-552, Elsevier.

Mickes, L., Moreland, M. B., Clark, S. E. and Wixted, J. T. 2014. Missing the information needed to perform ROC analysis? Then compute $d^{\prime}$, not the diagnosticity ratio. J. Appl. Res. Mem. Cogn., 3(2), 58-62. https://doi.org/10.1016/j.jarmac. 2014.04.007

National Registry of Exonerations. 2017. http:/www.law.umich.edu/ special/exoneration/Pages/about.aspx (accessed 2017-07-24).

Nortje, A. 2018. The butcher, the baker, the candlestick maker: Investigating facial recognition for multiple-perpetrator crimes. Doctoral dissertation. University of Cape Town, South Africa.

Nortje, A., Tredoux, C. G. and Vredeveldt, A. 2015, March. Remembering multiple faces is harder than you think! The effect of set size on face recognition. Paper presented at the American Psychology-Law Society Conference, San Diego, USA.

Nortje, A., Deglon, M., Tredoux, C. and Vredeveldt, A. 2016, November. Role and offender identification in multipleperpetrator crimes. Presentation at the Annual Face Science Seminar, Cape Town, South Africa.

Peirce, J. W. 2007. PsychoPy - Psychophysics software in Python. J. Neurosci. Methods, 162(1-2), 8-13. https://doi.org/ 10.1016/j.jneumeth.2006.11.017

Pica, E. and Pozzulo, J. 2018. Comparing younger and older adult eyewitnesses: Examining the simultaneous, elimination, and wildcard lineup procedures. Psychiatry Psychol. Law, 25(1), 106-123. https://doi.org/10.1080/13 218719.2017.1364614
Psychology Software Tools, Inc. [E-Prime 2.0]. 2017. http://www.pstnet.com

Salkind, N. J. (ed.). 2010. Encyclopedia of Research Design. SAGE Publications, Thousand Oaks, CA.

Sauerland, M. and Sporer, S. L. 2008. The application of multiple lineups in a field study. Psychol. Crime Law, 14(6), 549-564. https://doi.org/10.1080/10683160801972519

Sauerland, M., Stockmar, A. K., Sporer, S. L. and Broers, N. J. 2013. The reliability of identification evidence with multiple lineups. Eur. J. Psychol. Appl. Leg. Context, 5(1), 49-71.

Shepherd, J. W. 1983. Identification after long delays. In Evaluating Eyewitness Evidence (Lloyd-Bostock, S. M. A. and Clifford, B. R., eds), pp. 173-187, John Wiley \& Sons, Chichester.

Stroop, J. R. 1935. Studies of interference in serial verbal reactions. Exp. Psychol., 18, 643-662.

Sweller, J. 1988. Cognitive load during problem solving: Effect on learning. Cogn. Sci., 12(2), 257-285. https://doi.org/ 10.1016/0364-0213(88)90023-7

Sweller, J., Ayres, P. and Kalyuga, S. 2011. Cognitive Load Theory, vol. 1. Springer, New York, NY.

Technical Working Group for Eyewitness Evidence. 1999. Eyewitness Evidence: A Guide for Law Enforcement. U.S. Department of Justice, Office of Justice Programs, Washington, D.C.

Tredoux, C. G. 1998. Statistical inference on measures of lineup fairness. Law Hum. Behav., 22(2), 217-237. https://doi.org/ 10.1023/A:1025746220886

Vredeveldt, A., Hitch, G. J. and Baddeley, A. D. 2011. Eyeclosure helps memory by reducing cognitive load and enhancing visualisation. Mem. Cogn., 39, 1253-1263. https://doi.org/10.3758/s13421-011-0098-8

Wells, G. L. 1978. Applied eyewitness-testimony research: System variables and estimator variables. J. Pers. Soc. Psychol., 36(12), 1546-1557. https://doi.org/ 10.1037/00223514.36.12.1546

Wells, E. C. and Pozzulo, J. D. 2006. Accuracy of eyewitnesses with a two-culprit crime: Testing a new identification procedure. Psychol., Crime Law, 12(4), 417-427. https://doi.org/ 10.1080/10683160500050666

Wilcock, R., Crane, L., Hobson, Z., Nash, G., Kirke-Smith, M. and Henry, L. A. 2018. Supporting child witnesses during identification lineups: Exploring the effectiveness of registered intermediaries. Appl. Cogn. Psychol., 32(3), 367375. https://doi.org/101002/acp. 3412

Wixted, J. T. and Wells, G. L. 2017. The relationship between eyewitness confidence and identification accuracy: A new synthesis. Psychol. Sci. Public Interest, 18(1), 10-65. https://doi.org/10.1177/1529100616686966

Wixted, J. T., Mickes, L., Dunn, J. C., Clark, S. E. and Wells, W. 2016. Estimating the reliability of eyewitness identifications from police lineups. Proc. Natl. Acad. Sci. U.S.A., 113(2), 304-309. https://doi.org/ 10.1073/pnas.1516814112 


\title{
Kahtlustatavate äratundmiseks esitamise rea järjekord vs. teadmine, milline rida käib millise kahtlustatava kohta: aspekte mitme inimese tuvastamise täpsuses
}

\begin{abstract}
Kristjan Kask
Enamik pealtnägijatunnistusi käsitlevaid uurimusi on keskendunud ühe isiku tuvastamise täpsusele, samas kui paljudes kuritegudes võib tuvastatavaid isikuid olla rohkem kui üks. Eelnevad uuringud on välja toonud, et tugevad mälujäljed ja väike kognitiivne koormus on seotud inimeste tuvastamise suurema täpsusega. 180 katseisikut vaatas videot simuleeritud varguse episoodist, mis oli toime pandud kahe isiku poolt. Hiljem näidati katseisikutele kaht kuueliikmelist äratundmiseks esitamise rida eesmärgiga kahtlusalused tuvastada. Osa katseisikuid $(n=60)$ sai ise valida, kumba isikut esimesena tuvastada, osale katseisikutele tegi sellise valiku ridade läbiviija. Kui valiku tegi ridade läbiviija, siis olid katseisikud pooltel juhtudel teadlikud, milline rida millise isiku kohta käis $(n=60)$, ja pooltel juhtudel mitte $(n=60)$. Need katseisikud, kes said ridade esitamise järjekorra ise valida, lükkasid suuremal määral tagasi ridu, kus kahtlusalust polnud (65\%), võrreldes nendega, kellele ei öeldud, milline rida millise kahtlusaluse kohta käis (45\%). Nende katseisikute vahel, kes said ise ridade järjekorra valida, võrreldes nendega, kes ei saanud, aga kellele öeldi, milline rida millise isiku kohta käib, erinevusi ei ilmnenud. Teadlik olemine sellest, milline rida millise isiku kohta käib, on oluline faktor vähendamaks pealtnägijate kognitiivset koormust.
\end{abstract}

